\title{
Algorithm for Computer-Aided Construction of the Potential-pH Diagrams of Metal-Ion-Water Systems and Its Application to the Corrosion in Iodine-Iodide Solution*
}

\author{
Yoji Imai**, Kazuo Osato** and Hiroji Nakauchi** \\ ** National Chemical Laboratory for Industry
}

\begin{abstract}
An algorithm to construct the potential-pH diagram of metal-ion-water systems by using a computer was established and it is applied to the metal-iodine-water system to explain the corrosion behavior of metals in the environment corresponding to the first stage reaction of the MagnesiumIodine Cycle of thermochemical hydrogen production process. It is concluded that $\mathrm{Ta}, \mathrm{Zr}$, and Ti are thermodynamically protected owing to the oxide films which are more stable than iodides considered. On the contrary, noble metals such as $\mathrm{Au}, \mathrm{Ag}$, and $\mathrm{Pt}$ are predicted to corrode in concentrated iodine-iodide solution. Thermodynamic prediction is in fairly good agreement with the experimental results reported before.
\end{abstract}

Key words: corrosion, iodine, iodide, computer, potential-pH diagram, hydrogen production

\section{Introduction}

In realizing thermochemical hydrogen production from water, material selection and/or development for the equipments is one of the most important problems. The Magnesium-Iodine Cycle, which was proposed by the National Chemical Laboratory for Industry, Japan, is no exception. It is composed of four reactions as follows:

$$
\begin{aligned}
& 6 / 5 \mathrm{MgO}+6 / 5 \mathrm{I}_{2} \rightarrow \mathrm{MgI}_{2}+1 / 5 \mathrm{Mg}\left(\mathrm{IO}_{3}\right)_{2} \\
& 1 / 5 \mathrm{Mg}\left(\mathrm{IO}_{3}\right)_{2} \rightarrow 1 / 5 \mathrm{MgO}+1 / 5 \mathrm{I}_{2}+1 / 2 \mathrm{O}_{2} \\
& \mathrm{MgI}_{2}+\mathrm{H}_{2} \mathrm{O} \rightarrow \mathrm{MgO}+2 \mathrm{HI} \\
& 2 \mathrm{HI} \rightarrow \mathrm{H}_{2}+\mathrm{I}_{2}
\end{aligned}
$$

Among the four reactions, only the first stage reaction proceeds in aqueous solution. The corrosion behavior of metallic materials in this environment was already studied ${ }^{1)}$ and it is concluded that (1) $\mathrm{Ta}$ and $\mathrm{Nb}$ are perfectly protective, (2) $\mathrm{Zr}$ is protective under a limited condition, (3) Some $\mathrm{Ti}$ alloys (Ti-5Ta, Ti-10Mo) and Hastelloy-C are sometimes protective but sometimes non-protective, and (4) noble metals such as $\mathrm{Ag}$ and $\mathrm{Au}$ corrode very rapidly.

These corrosion behaviors may be explained from thermodynamic point of view, but the potenti-

* Presented at Annual Meeting of Japan Society of Corrosion Engineering in May, 1986 (Tokyo).

(Study on Construction Materials for the Magnesium-Iodine Cycle of Thermochemical Hydrogen Production Process, Part 8)

** 1-1, Higashi, Yatabe-machi, Tsukuba, Ibaraki 305, Japan.
al-pH (E-pH) diagrams, the most effective means of describing the thermodynamic relations of metaliodine-water systems, have not been reported yet.

Although principles of the E-pH diagram have been well-established, its construction is somewhat a cumbersome task, especially in the case where elements other than hydrogen, oxygen, and metal coexist because of the necessity of numerous calculations of Nernst's equation etc. and solution of sets of algebraic equations. The use of computer in the construction of the E-pH diagram was first proposed by Brook $^{2)}$ and was followed by several researchers ${ }^{3)}$ 7) for metal-water system. As for the metal-ion-water system, the algorithm proposed by Froning et $\mathrm{al}^{3}{ }^{3}$ is the only method that has a rigid base among algorithms categorized as a continuum type analysis ${ }^{6)}$ (not the 'point by point' analysis), and it has been extensively applied by Chen et $a l .{ }^{8)}$.

The purpose of the present paper is (1) to establish an improved algorithm for the construction of the E-pH diagram of metal-ion-water systems, and (2) to apply it to the metal-iodine-water systems so as to explain the corrosion behavior of metals in concentrated iodine solution.

\section{Algorithm for the Construction of E-pH Diagram}

For convenience sake, the algorithm is explained separately in the following two cases: (1) 'simple' system where the chemical species contain only one element other than oxygen and/or hydrogen 


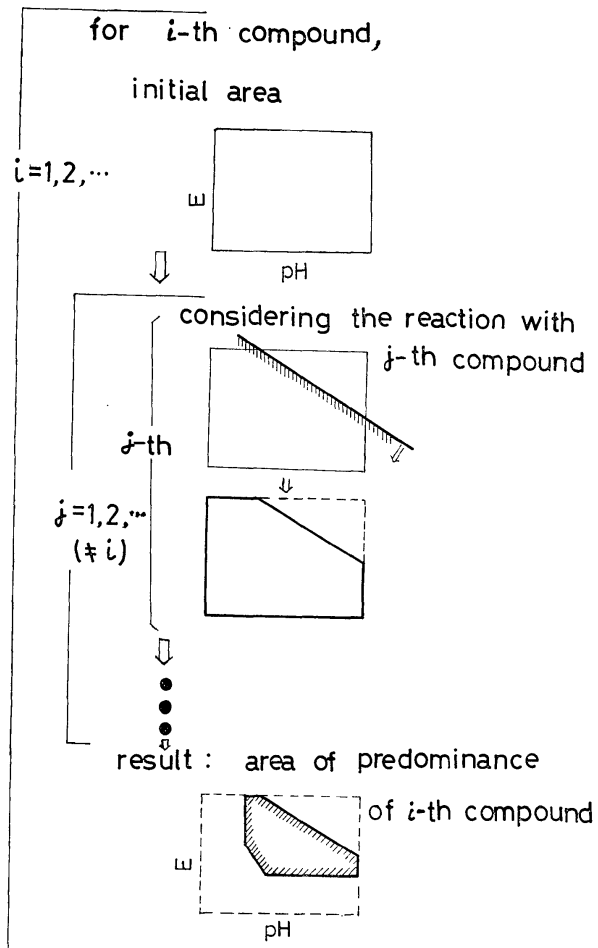

Fig. 1 Convex Polygon Method: Cosideration of equilibria of a species with other species one by one determines the limit of the a.p. of that species.

(species of the type of $\left\{\mathrm{Me}_{\mathrm{m} 1} \mathrm{O}_{\mathrm{x} 1} \mathrm{H}_{\mathrm{y} 1}{ }^{\mathrm{z} 1+}\right\}$ or $\left\{\mathrm{W}_{\mathrm{w} 2} \mathrm{O}_{\mathrm{x} 2} \mathrm{H}_{\mathrm{y} 2}{ }^{\mathrm{z} 2+}\right\}$ ), and (2) 'complex' system where the chemical species contain the second element (species of the type of $\left\{\mathrm{Me}_{\mathrm{m} 3} \mathrm{~W}_{\mathrm{w} 3} \mathrm{O}_{\mathrm{x} 3} \mathrm{H}_{\mathrm{y} 3}{ }^{23+}\right\}$ ). In the notation above and below, 'Me' denotes the metal to be considered and ' $\mathrm{W}$ ', the second element such as iodine, while ' $\mathrm{O}$ ' indicates oxygen. ' $\mathrm{H}$ ', ' $\mathrm{H}^{+}$' and ' $\mathrm{el}{ }^{-}$' indicate hydrogen, hydrogen ion, and an electon, respectively.

\subsection{Simple systems}

The method used here in the construction of the $\mathrm{E}$-pH diagram of a simple system is the same as that proposed by Froning et al. ${ }^{3}$, which is shown in Fig. 1 and described below. (Convex Polygon Method)

First, among all species to be considered, the 'area of predominance' (a.p.) of a species is determined in the E-pH diagram where it is more stable thermodynamically than any other species, by considering the reactions with all other species. For instance, the equilibrium of $\left\{\mathrm{Me}_{\mathrm{m} 1} \mathrm{O}_{\mathrm{x} 1} \mathrm{H}_{\mathrm{y} 1}{ }^{11+}\right\}$ with $\left\{\mathrm{Me}_{\mathrm{m} 2} \mathrm{O}_{\mathrm{x} 2} \mathrm{H}_{\mathrm{y} 2}{ }^{\mathrm{z} 2+}\right\}$ determines the limit of a.p. of the former substance because of the reaction, $\left[\mathrm{Me}_{\mathrm{m} 1} \mathrm{O}_{\mathrm{x} 1} \mathrm{H}_{\mathrm{y} 1}{ }^{21+}\right]+\mathrm{M} *\left[\mathrm{H}^{+}\right]+\mathrm{Z} *\left[\mathrm{el}^{-}\right]$

$$
\begin{aligned}
& =\mathrm{B} *\left[\mathrm{Me}_{\mathrm{m} 2} \mathrm{O}_{\mathrm{x} 2} \mathrm{H}_{\mathrm{y} 2}{ }^{\mathrm{z} 2+}\right]+\mathrm{C} *\left[\mathrm{H}_{2} \mathrm{O}\right], \\
& \text { where }{ }^{8)} \\
& \begin{array}{c}
\mathrm{M}=(\mathrm{m} 2 / \mathrm{m} 1) *(\mathrm{y} 2-2 * \mathrm{x} 2)+(2 * \mathrm{x} 1-\mathrm{y} 2), \\
Z=\{z 1-(\mathrm{m} 1 / \mathrm{m} 2) * z 2\} \\
+(\mathrm{m} 1 / \mathrm{m} 2) *(\mathrm{y} 2-2 * \mathrm{x} 2)+(2 * \mathrm{x} 1-\mathrm{y} 1), \\
\mathrm{B}=\mathrm{m} 1 / \mathrm{m} 2, \quad \mathrm{C}=\mathrm{x} 1-(\mathrm{m} 1 / \mathrm{m} 2) * \mathrm{x} 2 .
\end{array}
\end{aligned}
$$

The chemical species $\left\{\mathrm{Me}_{\mathrm{m} 1} \mathrm{O}_{\mathrm{x} 1} \mathrm{H}_{\mathrm{y} 1}{ }^{\mathrm{z} 1+}\right\}$ is more stable than $\left\{\mathrm{Me}_{\mathrm{m} 2} \mathrm{O}_{\mathrm{x} 2} \mathrm{H}_{\mathrm{y} 2}{ }^{22+}\right\}$ in the region where the following inequality is satisfied

$$
\begin{aligned}
\mathrm{E}>\mathrm{E}^{\circ}-(\mathrm{RT} / \mathrm{ZF}) * \mathrm{M} * 2.303 * \mathrm{pH} \\
+(\mathrm{RT} / \mathrm{ZF}) * 2.303 * \log \left\{\mathrm{a}_{1} / \mathrm{a}_{2}{ }^{\mathrm{B}}\right\}
\end{aligned}
$$

if $Z>0 * 1)$. In the above equation, $R$ is gas constant, $\mathrm{T}$ is absolute temperature, $\mathrm{F}$ is Faraday's constant. $\mathrm{a}_{1}$ and $\mathrm{a}_{2}$ are the activities of $\left\{\mathrm{Me}_{\mathrm{m} 1} \mathrm{O}_{\mathrm{x} 1} \mathrm{H}_{\mathrm{y} 1}{ }^{11+}\right\}$ and $\left\{\mathrm{Me}_{\mathrm{m} 2} \mathrm{O}_{\mathrm{x} 2} \mathrm{H}_{\mathrm{y} 2}{ }^{\mathrm{z} 2+}\right\}$, respectively. The value of $\mathrm{E}^{\circ}$ is calculated from the Gibbs energy of the species at T. By considering all of this kind of inequalities which represent the equilibria with other species $\left(\mathrm{Me}_{\mathrm{m} 3} \mathrm{O}_{\mathrm{x} 3} \mathrm{H}_{\mathrm{y} 3}{ }^{{ }^{23+} \text {, }}\right.$ $\left.\mathrm{Me}_{\mathrm{m} 4} \mathrm{O}_{\mathrm{x} 4} \mathrm{H}_{\mathrm{y} 4}{ }^{\mathrm{z}+}, \cdots\right)$, the a.p. of $\left\{\mathrm{Me}_{\mathrm{m} 1} \mathrm{O}_{\mathrm{x} 1} \mathrm{H}_{\mathrm{y} 1}{ }^{\mathrm{z} 1+}\right\}$ is determined as the area where all the inequalities are satisfied simultaneously.

Secondly, each a.p. of the species considered is compiled, resulting in the E-pH diagram of Me$\mathrm{H}_{2} \mathrm{O}$. The same procedure is valid in the costruction of the E-pH diagram of $\mathrm{W}-\mathrm{H}_{2} \mathrm{O}$ system.

\subsection{Area of Predominance of Complex Systems}

For the Me-W- $\mathrm{H}_{2} \mathrm{O}$ system in which element W has its own E-pH equilibria (e.g. $\mathrm{HI}, \mathrm{I}^{-}$, and $\mathrm{I}_{2}$ ), the E-pH diagram cannot be determined by the Convex Polygon Method described above directly, since the a.p. does not always constitute a convex polygon ${ }^{* 2)}$. Froning et al $^{3)}$ and Chen et al.$^{8)}$ used the following procedure: (1) to determine the a.p. of the species of the second element, W (e.g., HI, $\left.I^{-}, I_{2}, \cdots\right)$, (2) to determine the additional diagrams (one for each of the second element species) for the redox system containing the first element $(\mathrm{Me})$ and each second element species, individually, and (3) to construct the final diagram by using the appropriate portion of each of the additional diagrams, by taking into account the a.p. of each of second species.

*1) When $\mathrm{Z}<0$, the direction of inequality sign is reverse. When $\mathrm{Z}=0$, the boundary line of the area of predominance is vertical on the E-pH diagram.

*2) There are cases where the a.p. of Me-W-O-H compound $\left(\mathrm{Me}_{\mathrm{m} 3} \mathrm{~W}_{\mathrm{W} 3} \mathrm{O}_{\mathrm{x} 3} \mathrm{H}_{\mathrm{y} 3}{ }^{\mathrm{z} 3+}\right)$ has an interior angle larger than $\pi$ radian at the boundaries of the a.p.'s on the E-pH diagrams of $\mathrm{Me}^{-} \mathrm{H}_{2} \mathrm{O}$ and $\mathrm{W}-\mathrm{H}_{2} \mathrm{O}$, as is shown in the example of $\mathrm{Fe}-\mathrm{S}-\mathrm{H}_{2} \mathrm{O}$ system $^{17)}$. 
(a)"Polygon Test"
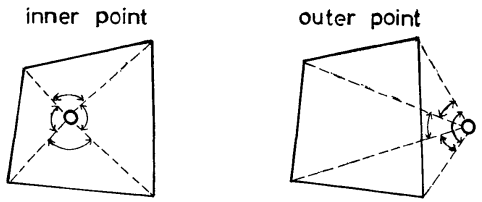

(b) Arrangement of the order of the vertices

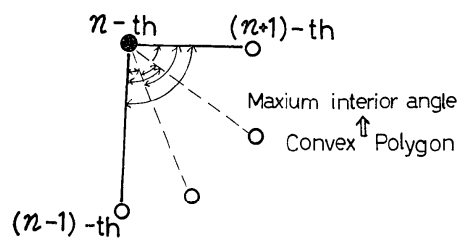

Fig. 2 (a) Polygon Test: When the sum of the interior angles around a certain point between two adjacent vertices of a polygon is $2 \pi$ radian, that point is an inner point of that polygon, and vice versa.

(b) Principle of maximum interior angle: The interior angle around a certain vertex has the biggest value when the candidates of the adjacent (fore- and hind-) vertices of that vertex is chosen rightly in a convex polygon. This principle is applied in order to arrange the candidate vertices in proper order.

The above procedure is rigorously correct in resolving equilibria between the first element species and the second element species, and therefore, never fails to construct a diagram. However, this algorithm executes unnecessary computation in the construction of additional diagrams in step (2), resulting in consumption of computer time and memory area than minimum requirement. This disadvantage seems to be serious when chemical species contain the third (or fourth, etc.) element that has its own E-pH equilibria (e.g. the case where $\mathrm{FeI}_{2} \cdot 2 \mathrm{NH}_{3}$ is formed).

The algorithm proposed in this paper for determination of the a.p. of the Me-W-O-H compound $\left(\mathrm{Me}_{\mathrm{m} 3} \mathrm{~W}_{\mathrm{w} 3} \mathrm{O}_{\mathrm{x} 3} \mathrm{H}_{\mathrm{y} 3}{ }^{\mathrm{z}+}\right)$ is as follows: (1) to determine the common area of the a.p. of Me-O-H compound $\left(\mathrm{Me}_{\mathrm{m} 1} \mathrm{O}_{\mathrm{x} 1} \mathrm{H}_{\mathrm{y} 1}{ }^{\mathrm{z} 1+}\right)$ and the a.p. of $\mathrm{W}$ O-H compound $\left(\mathrm{W}_{\mathrm{w} 2} \mathrm{O}_{\mathrm{x} 2} \mathrm{H}_{\mathrm{y} 2}{ }^{\mathrm{z} 2+}\right)$, (2) to apply the Convex Polygon Method ${ }^{* 3}$ ) to the determination

*3) Note that the a.p. of Me-W-O-H compound is convex if we consider it on the common area of the a.p.'s of $\left\{\mathrm{Me}_{\mathrm{m} 1} \mathrm{O}_{\mathrm{x} 1} \mathrm{H}_{\mathrm{y} 1}{ }^{\mathrm{z} 1+}\right\}$ and $\left\{\mathrm{W}_{\mathrm{w} 2} \mathrm{O}_{\mathrm{x} 2}\right.$ $\mathrm{H}_{\mathrm{y2}}{ }^{\mathrm{z} 2+}$, , though the a.p. of Me-W-O-H compound on the whole region of the E-pH diagram is not always convex. of the a.p. of $\left\{\mathrm{Me}_{\mathrm{m} 3} \mathrm{~W}_{\mathrm{w} 3} \mathrm{O}_{\mathrm{x} 3} \mathrm{H}_{\mathrm{y} 3}{ }^{{ }^{33}+}\right\}$ within the area limited in step (1), by considering the reaction with $\left\{\mathrm{Me}_{\mathrm{m} 1} \mathrm{O}_{\mathrm{x} 1} \mathrm{H}_{\mathrm{y} 1}{ }^{21+}\right\},\left\{\mathrm{Me}_{\mathrm{m} 4} \mathrm{~W}_{\mathrm{w} 4} \mathrm{O}_{\mathrm{x} 4} \mathrm{H}_{\mathrm{y} 4}{ }^{44+}\right\},\left\{\mathrm{Me}_{\mathrm{m} 5^{-}}\right.$ $\left.\mathrm{W}_{\mathrm{w} 5} \mathrm{O}_{\mathrm{x} 5} \mathrm{H}_{\mathrm{y} 5}{ }^{\mathrm{z} 5}+\right\}, \cdots$, and $\left\{\mathrm{W}_{\mathrm{w} 2} \mathrm{O}_{\mathrm{x} 2} \mathrm{H}_{\mathrm{y} 2}{ }^{22+}\right\}$, and (3) to conduct the step (1) and (2) for all the possible pairs of Me-O-H compounds and W-O-H compounds, resulting in the determination of a.p. of $\left\{\mathrm{Me}_{\mathrm{m} 3} \mathrm{~W}_{\mathrm{w} 3} \mathrm{O}_{\mathrm{x} 3} \mathrm{H}_{\mathrm{y} 3}{ }^{23+}\right\}$ on the whole region of the E-pH diagram.

The procedure for the determination of the common area of two a.p.'s (step (1)) is as follows: (1-a) to check if the vertices, which determine the a.p. of $\left\{\mathrm{Me}_{\mathrm{m} 1} \mathrm{O}_{\mathrm{x} 1} \mathrm{H}_{\mathrm{y} 1}{ }^{\mathrm{z} 1+}\right\}$ are the inner point of the a.p. of $\left\{\mathrm{W}_{\mathrm{w} 2} \mathrm{O}_{\mathrm{x} 2} \mathrm{H}_{\mathrm{y} 2}{ }^{\mathrm{z} 2+}\right\}$ or not (If so, those points are the candidates of the vertices of the common area.), (1-b) to check if the vertices, which determine the a.p. of $\left\{\mathrm{W}_{\mathrm{w} 2} \mathrm{O}_{\mathrm{x} 2} \mathrm{H}_{\mathrm{y} 2}{ }^{2+}+\right\}$ are the inner point of the a.p. of $\left\{\mathrm{Me}_{\mathrm{m} 1} \mathrm{O}_{\mathrm{x} 1} \mathrm{H}_{\mathrm{y} 1}{ }^{21+}\right\}$ or not (If so, those points are also the candidates of the vertices of the common area.), (1-c) to check if the sides of the a.p. of $\left\{\mathrm{Me}_{\mathrm{m} 1} \mathrm{O}_{\mathrm{x} 1} \mathrm{H}_{\mathrm{y} 1}{ }^{1+}\right\}$ intersect with those of the a.p. of $\left\{\mathrm{W}_{\mathrm{w} 2} \mathrm{O}_{\mathrm{x} 2} \mathrm{H}_{\mathrm{y} 2}{ }^{2+}\right\}$ (If so, the points of intersection are the candidates of the vertices of the common area.), and (1-d) to arrange the order of the candidates, which were determined in steps (1-a) (1-c), to make a convex polygon.

In the steps (1-a) and (1-b), the so-called 'polygon test' in computer graphics ${ }^{9)}$ is used; that is, if a point is inner point in the polygon, then the sum of the interior angles around that point between two adjacent vertices of the polygon is $2 \pi$ radian, as shown in Fig. 2 (a). In the step (1-d), the 'principle of maximum interior angle' for convex polygon*4), shown in Fig. 2 (b), is applied.

The balancing equation used in $\operatorname{step}(2)$ for the reaction of $\left\{\mathrm{Me}_{\mathrm{m} 3} \mathrm{~W}_{\mathrm{w} 3} \mathrm{O}_{\mathrm{x} 3} \mathrm{H}_{\mathrm{y} 3}{ }^{23+}\right\}$ and $\left\{\mathrm{Me}_{\mathrm{m} 4}{ }^{-}\right.$ $\mathrm{W}_{\mathrm{w} 4} \mathrm{O}_{\mathrm{x} 4} \mathrm{H}_{\mathrm{y} 4}{ }^{24+}$ \} (when $\mathrm{w} 4=0$, the latter also represents the Me-O-H compound) is as follows:

$$
\begin{gathered}
{\left[\mathrm{Me}_{\mathrm{m} 3} \mathrm{~W}_{\mathrm{w} 3} \mathrm{O}_{\mathrm{x} 3} \mathrm{H}_{\mathrm{y} 3}{ }^{23+}\right]+\mathrm{M} *\left[\mathrm{H}^{+}\right]} \\
+\mathrm{A} *\left[\mathrm{~W}_{\mathrm{w} 2} \mathrm{O}_{\mathrm{x} 2} \mathrm{H}_{\mathrm{y} 2}{ }^{2+}\right]+\mathrm{Z} *\left[\mathrm{el}^{-}\right] \\
=\mathrm{B} *\left[\mathrm{Me}_{\mathrm{m} 4} \mathrm{~W}_{\mathrm{w} 4} \mathrm{O}_{\mathrm{x} 4} \mathrm{H}_{\mathrm{y} 4}{ }^{\mathrm{k}++}\right]+\mathrm{C} *\left[\mathrm{H}_{2} \mathrm{O}\right],
\end{gathered}
$$

where

$$
\begin{aligned}
\mathrm{M}= & -\mathrm{y} 3-(\mathrm{y} 2 / \mathrm{w} 2) *(\mathrm{~m} 3 * \mathrm{w} 4 / \mathrm{m} 4-\mathrm{w} 3) \\
& +2 * \mathrm{x} 3+2 * \mathrm{x} 2 *(\mathrm{~m} 3 * \mathrm{w} 4 / \mathrm{m} 4-\mathrm{w} 3) / \mathrm{w} 2 \\
& -2 * \mathrm{~m} 3 * \mathrm{x} 4 / \mathrm{m} 4+\mathrm{m} 3 * \mathrm{y} 4 / \mathrm{m} 4, \\
\mathrm{~A}= & (\mathrm{m} 3 * \mathrm{w} 4 / \mathrm{m} 4-\mathrm{w} 3) / \mathrm{w} 2, \\
\mathrm{Z}= & \mathrm{z} 3+\mathrm{z} 2 *(\mathrm{~m} 3 * \mathrm{w} 4 / \mathrm{m} 4-\mathrm{w} 3) / \mathrm{w} 2 \\
& -\mathrm{m} 3 * \mathrm{z} 4 / \mathrm{m} 4-\mathrm{y} 3-\mathrm{y} 2 *(\mathrm{~m} 3 * \mathrm{w} 4 / \mathrm{m} 4 \\
& -\mathrm{w} 3) / \mathrm{w} 2+2 * \mathrm{x} 3+2 * \mathrm{x} 2 *(\mathrm{~m} 3 * \mathrm{w} 4 / \mathrm{m} 4 \\
& -\mathrm{w} 3) / \mathrm{w} 2-2 * \mathrm{~m} 3 * \mathrm{x} 4 / \mathrm{m} 4+\mathrm{m} 3 * \mathrm{y} 4 / \mathrm{m} 4, \\
\mathrm{~B}= & \mathrm{m} 3 / \mathrm{m} 4,
\end{aligned}
$$

*4) This algorithm is valid because the common area of two convex polygon is also convex. 
(a)

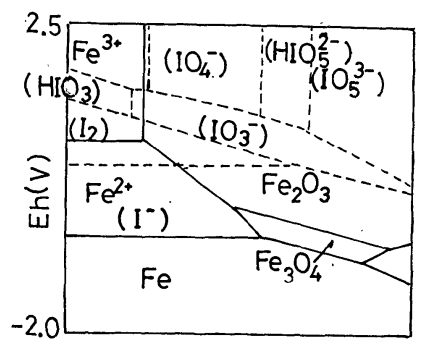

(b)

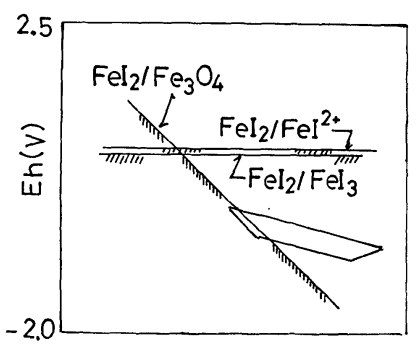

(c)

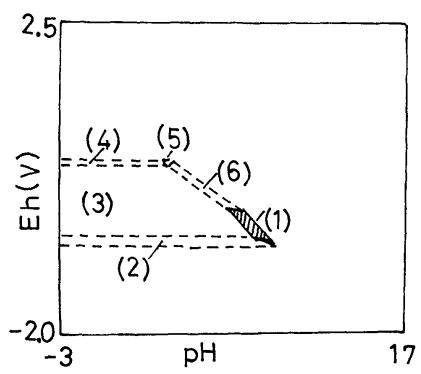

Fig. 3 Schematic diagram of the process for determination of the area of predominance of Me-W-O-H compound.

(a) E-pH diagram of $\mathrm{Fe}-\mathrm{H}_{2} \mathrm{O}(-)$ and I$\mathrm{H}_{2} \mathrm{O}(-----)$.

(b) Equilibria of $\mathrm{FeI}_{2}$ with $\left\{\mathrm{Fe}_{3} \mathrm{O}_{4}, \mathrm{FeI}_{3}\right.$, or $\left.\mathrm{FeI}^{2+}\right\}$ and $\left\{\mathrm{I}^{-}, \mathrm{H}^{+}, \mathrm{el}^{-}\right.$, and $\left.\mathrm{H}_{2} \mathrm{O}\right\}$ give the area of predominance of $\mathrm{FeI}_{2}$ within the common region of the a.p.'s of $\mathrm{Fe}_{3} \mathrm{O}_{4}$ and I'(c) Area of predominance of $\mathrm{FeI}_{2}$.

$\mathrm{C}=\mathrm{x} 3+\mathrm{x} 2 *(\mathrm{~m} 3 * \mathrm{w} 4 / \mathrm{m} 4-\mathrm{w} 3) / \mathrm{w} 2-\mathrm{m} 3 * \mathrm{x} 4 / \mathrm{m} 4$. $\left\{\mathrm{Me}_{\mathrm{m} 3} \mathrm{~W}_{\mathrm{w} 3} \mathrm{O}_{\mathrm{x} 3} \mathrm{H}_{\mathrm{y} 3}{ }^{{ }^{3}+}\right\}$ is more stable than $\left\{\mathrm{Me}_{\mathrm{m} 4^{-}}\right.$ $\left.\mathrm{W}_{\mathrm{w} 4} \mathrm{O}_{\mathrm{x} 4} \mathrm{H}_{\mathrm{y} 4}{ }^{24+}\right\}$ in the region which satisfy the following inequality

$$
\begin{aligned}
\mathrm{E}>\mathrm{E}^{\circ}- & (\mathrm{RT} / \mathrm{ZF}) * \mathrm{M} * 2.303 * \mathrm{pH} \\
& +(\mathrm{RT} / \mathrm{ZF}) * 2.303 * \log \left\{\mathrm{a}_{3} * \mathrm{a}_{2}{ }^{\mathrm{A}} / \mathrm{a}_{4}{ }^{\mathrm{B}}\right\}
\end{aligned}
$$

if $Z>0^{* 11}$, where $a_{3}, a_{2}$, and $a_{4}$ are the activities of $\left\{\mathrm{Me}_{\mathrm{m} 3} \mathrm{~W}_{\mathrm{w} 3} \mathrm{O}_{\mathrm{x} 3} \mathrm{H}_{\mathrm{y} 3}{ }^{23+}\right\}, \quad\left\{\mathrm{W}_{\mathrm{w} 2} \mathrm{O}_{\mathrm{x} 2} \mathrm{H}_{\mathrm{y} 2}{ }^{22+}\right\}, \quad$ and $\left\{\mathrm{Me}_{\mathrm{m} 4} \mathrm{~W}_{\mathrm{w} 4} \mathrm{O}_{\mathrm{x} 4} \mathrm{H}_{\mathrm{y} 4}{ }^{\mathrm{z}+}\right\}$, respectively.

Fig. 3 shows the example of the process to determine the a.p. of $\mathrm{FeI}_{2}$ assuming the activities of dissolved iodine compounds be 10 . Fig. 3 (a) represents the E-pH diagram of $\mathrm{Fe}-\mathrm{H}_{2} \mathrm{O}$ and I$\mathrm{H}_{2} \mathrm{O}$. The quadrangular area in Fig. 3 (b) is the common area of the a.p.'s of $\mathrm{Fe}_{3} \mathrm{O}_{4}$ in $\mathrm{Fe}-\mathrm{H}_{2} \mathrm{O}$ system and that of $\mathrm{I}^{-}$in $\mathrm{I}_{-} \mathrm{H}_{2} \mathrm{O}$ system. Consideration of the equilibria of $\mathrm{FeI}_{2}$ with $\left\{\mathrm{Fe}_{3} \mathrm{O}_{4}\right.$, $\mathrm{FeI}^{2+}$, or $\left.\mathrm{FeI}_{3}\right\}$ and $\left\{\mathrm{H}^{+}, \mathrm{I}^{-}, \mathrm{el}^{-}\right.$and $\left.\mathrm{H}_{2} \mathrm{O}\right\}$ on the above quadrangular area determines the a.p. of $\mathrm{FeI}_{2}$ within that area ${ }^{* 5)}$. The shaded area, assigned number of which is (1) in Fig. 3 (c), expresses the a.p. of $\mathrm{FeI}_{2}$ within that area, thus determined. By considering all the pairs of $\left(\mathrm{Fe}^{3+}\right.$, $\mathrm{Fe}^{2+}$, etc. $)$ and $\left(\mathrm{I}^{-}, \mathrm{I}_{2}, \mathrm{IO}_{3}{ }^{-}\right.$, etc $)$, the a.p. of $\mathrm{FeI}_{2}$ is determined as shown in Fig. 3 (c). The areas (2) (6) in Fig. 3 (c) represents the a.p. of $\mathrm{FeI}_{2}$ from the pairs of $\left(\mathrm{Fe}, \mathrm{I}^{-}\right),\left(\mathrm{Fe}^{2+}, \mathrm{I}^{-}\right),\left(\mathrm{Fe}_{2} \mathrm{O}_{3}\right.$, $\left.\mathrm{I}_{2}\right)$, and $\left(\mathrm{Fe}_{2} \mathrm{O}_{3}, \mathrm{I}^{-}\right)$, respectively.

\subsection{Potential-pH Diagrams of Complex systems}

After the completion of steps (1) (3) in 2.2, the E-pH diagram of $\mathrm{Me}-\mathrm{W}-\mathrm{H}_{2} \mathrm{O}$ is expressed as the overlap of the 'virtual' E-pH diagram of Me$\mathrm{H}_{2} \mathrm{O}$, which is determined by the algorithm in 2.1 under the assumption that no $\mathrm{W}$ species exist in the system, and the a.p.'s of Me-W-O-H compounds determined by the method in 2.2 .

That is, (1) The each of a.p. of Me-W-O-H compound is just the same as determined in 2.2, and (2) The a.p. of Me-O-H compound on the E$\mathrm{pH}$ diagram of $\mathrm{Me}-\mathrm{W}-\mathrm{H}_{2} \mathrm{O}$ is the area which is determined by exclusion of the a.p.'s of $\mathrm{Me}-\mathrm{W}$ $\mathrm{O}-\mathrm{H}$ compounds from the a.p. of that $\mathrm{Me}-\mathrm{O}-\mathrm{H}$ compound on the 'virtual' E-pH diagram of Me$\mathrm{H}_{2} \mathrm{O}$.

The algorithm developed here is easily expanded into the cases where chemical species contain more than two elements besides oxygen, hydrogen, and metal.

\section{On the Thermodynamic Data}

Values of Gibbs energy and related quantities (e.g., stability constants of coordination compounds) to calculate the equilibria exist sporadical-

*5) The reactions of $\mathrm{FeI}_{2}$ with $\mathrm{Fe}_{3} \mathrm{O}_{4}, \mathrm{FeI}^{2+}$, or $\mathrm{FeI}_{3}$ on the common area of a.p.'s of $\mathrm{Fe}_{3} \mathrm{O}_{4}$ on $\mathrm{Fe}-\mathrm{H}_{2} \mathrm{O}$ system and $\mathrm{I}^{-}$on $\mathrm{I}_{-} \mathrm{H}_{2} \mathrm{O}$ system are as follows:

$\mathrm{FeI}_{2}+(-8 / 3) * \mathrm{H}^{+}+(-2) * \mathrm{I}^{-}+(-2 / 3) * \mathrm{el}^{-}$

$=(1 / 3) * \mathrm{Fe}_{3} \mathrm{O}_{4}+(-4 / 3) * \mathrm{H}_{2} \mathrm{O}$,

$\mathrm{FeI}_{2}+(-1) * \mathrm{I}^{-}+(-1) * \mathrm{el}^{-}=\mathrm{FeI}^{2+}$,

$\mathrm{FeI}_{2}+1 * \mathrm{I}^{-}+(-1) * \mathrm{el}^{-}=\mathrm{FeI}_{3}$.

$\mathrm{FeI}_{2}$ is stable in the area where the following inequalities, which correspond to the above reactions, are simulatneously satisfied.

$$
\begin{aligned}
& \mathrm{E}<1.5873-0.2367 * \mathrm{pH}, \\
& \mathrm{E}<0.716, \quad \mathrm{E}<0.710 .
\end{aligned}
$$


Table 1. List of values of Gibbs energy.

\begin{tabular}{|c|c|}
\hline ELEM. & 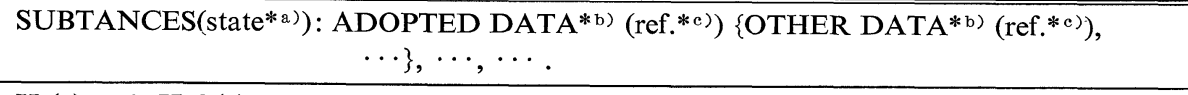 \\
\hline $\mathbf{H}$ & $\mathrm{H}_{2}(\mathrm{~g}): 0.0, \mathrm{H}_{2} \mathrm{O}(1):-56.7(\mathrm{P}, \mathrm{N}, \mathrm{B})$ \\
\hline I & $\begin{array}{l}\mathrm{I}_{2}(\mathrm{~s}): 0.0, \mathrm{I}^{-}(\mathrm{aq}):-12.35(\mathrm{P}), \mathrm{I}_{3}{ }^{-}(\mathrm{aq}):-12.31(\mathrm{P}), \mathrm{I}^{+}(\mathrm{aq}): 31.29(\mathrm{P}), \mathrm{HIO}(\mathrm{aq}):-23.5(\mathrm{P}), \\
\mathrm{IO}^{-}(\mathrm{aq}):-8.5(\mathrm{P}), \mathrm{HIO}_{3}(\mathrm{aq}):-33.34(\mathrm{P}), \mathrm{IO}_{3}{ }^{-}(\mathrm{aq}):-32.25(\mathrm{P}), \mathrm{HIO}_{4}(\mathrm{aq}):-15.02(\mathrm{P}) \\
\mathrm{IO}_{4}{ }^{-}(\mathrm{aq}):-12.7(\mathrm{P}), \mathrm{HIO}_{5}{ }^{2-}(\mathrm{aq}):-58.11(\mathrm{P}), \mathrm{IO}_{5}{ }^{3-}(\mathrm{aq}):-43.11(\mathrm{P})\end{array}$ \\
\hline $\mathrm{Ag}$ & 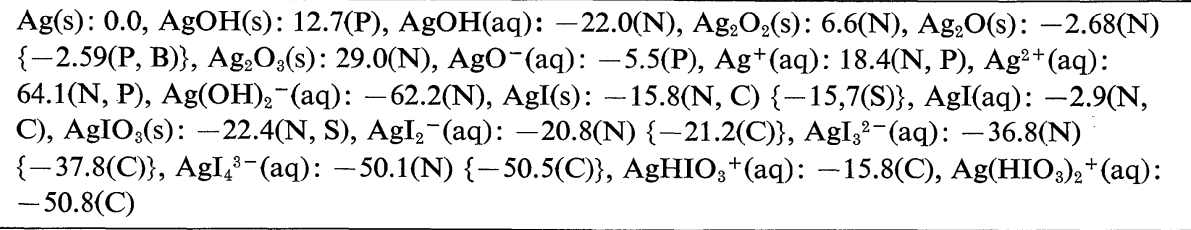 \\
\hline $\mathrm{Au}$ & $\begin{array}{l}\mathrm{Au}(\mathrm{s}): 0.0, \mathrm{Au}(\mathrm{OH})_{3}(\mathrm{aq}):-75.8(\mathrm{I}), \mathrm{Au}(\mathrm{OH})_{3}(\mathrm{~s}):-67.8(\mathrm{I}), \mathrm{Au}^{+}(\mathrm{aq}): 42.0(\mathrm{I}), \mathrm{Au}^{3+}(\mathrm{aq}): \\
\text { 105.2(I), } \mathrm{AuO}_{3}{ }^{3-}(\mathrm{aq}):-12.4(\mathrm{I}), \mathrm{HAuO}_{3}{ }^{2-}(\mathrm{aq}):-33.9(\mathrm{I}), \mathrm{H}_{2} \mathrm{AuO}_{3}{ }^{-}(\mathrm{aq}):-52.1(\mathrm{I}), \mathrm{AuI}(\mathrm{s}): \\
-0.12(\mathrm{I}), \mathrm{AuI}_{2}{ }^{-}(\mathrm{aq}):-11.4(\mathrm{I}), \mathrm{AuI}_{4}{ }^{-}(\mathrm{aq}):-10.8(\mathrm{I})\end{array}$ \\
\hline $\mathrm{Co}$ & $\begin{array}{l}\mathrm{Co}(\mathrm{s}): 0.0, \mathrm{CoO}(\mathrm{s}):-51.2(\mathrm{~N}):\{-51.4(\mathrm{~B})\}, \mathrm{Co}(\mathrm{OH})_{2}(\mathrm{aq}):-100.8(\mathrm{~N}), \mathrm{Co}(\mathrm{OH})_{2}(\mathrm{~s}):-109.5 \\
(\mathrm{~N})\left\{-109.0\left(\mathrm{P}^{\prime}\right)\right\}, \mathrm{Co}_{3} \mathrm{O}_{4}(\mathrm{~s}):-185.0(\mathrm{~N})\{-188.0(\mathrm{~B})\}, \mathrm{Co}(\mathrm{OH})_{3}(\mathrm{~s}):-142.6\left(\mathrm{P}^{\prime}\right), \mathrm{CoO}_{2}(\mathrm{~s}): \\
-51.8(\mathrm{P}), \mathrm{Co}^{2+}(\mathrm{aq}):-13.0(\mathrm{~N}), \mathrm{Co}^{3+}(\mathrm{aq}): 32.0(\mathrm{~N}), \mathrm{HCoO}_{2}{ }^{-}(\mathrm{aq}):-97.4(\mathrm{~N}), \mathrm{CoI}_{2}(\mathrm{~s}):-21.7 \\
(\mathrm{~B}), \mathrm{CoI}_{2}(\mathrm{aq}):-37.7(\mathrm{~N}), \mathrm{Co}\left(\mathrm{IO}_{3}\right)_{2}(\mathrm{~s}):-85.0(\mathrm{~S}), \mathrm{Co}\left(\mathrm{IO}_{3}\right)_{2}(\mathrm{aq}):-74.2(\mathrm{~N}), \mathrm{Co}\left(\mathrm{IO}_{3}\right)_{2} \cdot 2 \mathrm{H}_{2} \mathrm{O}(\mathrm{s}): \\
-190.2(\mathrm{~N})\end{array}$ \\
\hline $\mathrm{Cr}$ & $\begin{array}{l}\mathrm{Cr}(\mathrm{s}): 0.0, \mathrm{Cr}(\mathrm{OH})_{2}(\mathrm{~s}):-140.5\left(\mathrm{P}^{\prime}\right), \mathrm{Cr}(\mathrm{OH})_{3}(\mathrm{~s}):-215.3\left(\mathrm{P}^{\prime}\right), \mathrm{Cr}(\mathrm{OH})_{4}(\mathrm{~s}):-242.4\left(\mathrm{P}^{\prime}\right), \\
\mathrm{Cr}_{2} \mathrm{O}_{3}(\mathrm{~s}):-250.2(\mathrm{P})\{-250.5(\mathrm{~B})\}, \mathrm{CrO}_{2}(\mathrm{~s}):-126.3(\mathrm{~B}), \mathrm{Cr}_{5} \mathrm{O}_{12}(\mathrm{~s}):-626.6(\mathrm{~B}), \mathrm{CrO}_{3}(\mathrm{~s}): \\
-120.0(\mathrm{P}, \mathrm{B}), \mathrm{Cr}_{8} \mathrm{O}_{21}(\mathrm{~s}):-987.7(\mathrm{~B}), \mathrm{Cr}^{2+}(\mathrm{aq}):-42.1(\mathrm{P}), \mathrm{CrO}_{4}{ }^{2-}(\mathrm{aq}):-176.1(\mathrm{P}), \mathrm{Cr}_{2} \mathrm{O}_{7}{ }^{2-} \\
(\mathrm{aq}):-315.4(\mathrm{P}), \mathrm{Cr}^{3+}(\mathrm{aq}):-51.5(\mathrm{P}), \mathrm{Cr}(\mathrm{OH})_{2}{ }^{+}(\mathrm{aq}):-151.2(\mathrm{P}), \mathrm{CrO}_{2}{ }^{-}(\mathrm{aq}):-128.1(\mathrm{P}), \\
\mathrm{CrO}_{3}{ }^{3-}(\mathrm{aq}):-144.2(\mathrm{P}), \mathrm{HCrO}_{4}{ }^{-}(\mathrm{aq}):-184.9(\mathrm{P}), \mathrm{CrI}_{2}(\mathrm{~s}):-39.9(\mathrm{~B}), \mathrm{CrI}_{3}(\mathrm{a}):-49.1(\mathrm{~B}), \\
\mathrm{Cr}\left(\mathrm{IO}_{3}\right)_{2}{ }^{+}(\mathrm{aq}):-113.1(\mathrm{~S}), \mathrm{Cr}\left(\mathrm{HIO}_{3}\right)_{2}{ }^{3+}(\mathrm{aq}):-121.1(\mathrm{C})\end{array}$ \\
\hline $\mathrm{Cu}$ & $\begin{array}{l}\mathrm{Cu}(\mathrm{s}): 0.0, \mathrm{Cu}^{+}(\mathrm{aq}): 12.0(\mathrm{~N}), \mathrm{Cu}^{2+}(\mathrm{aq}): 15.7(\mathrm{~N}), \mathrm{Cu}(\mathrm{OH})_{2}(\mathrm{~s}):-85.3\left(\mathrm{P}^{\prime}\right), \mathrm{Cu}(\mathrm{OH})_{2}(\mathrm{aq}): \\
-59.5(\mathrm{~N}), \mathrm{CuO}(\mathrm{s}):-31.0(\mathrm{~N}), \mathrm{Cu}_{2} \mathrm{O}(\mathrm{s}):-35.0(\mathrm{~N}), \mathrm{HCuO}_{2}-(\mathrm{aq}):-61.8(\mathrm{~N}), \mathrm{CuO}_{2}{ }^{2-}(\mathrm{aq}): \\
-43.9(\mathrm{~N}), \mathrm{CuI}(\mathrm{s}):-16.6(\mathrm{~N}), \mathrm{Cu}\left(\mathrm{IO}_{3}\right)_{2}(\mathrm{~s}):-57.3(\mathrm{~S}), \mathrm{Cu}\left(\mathrm{IO}_{3}\right)_{2}(\mathrm{aq}):-45.5(\mathrm{~N}), \mathrm{Cu}\left(\mathrm{IO}_{3}\right)_{2} \\
\mathrm{H}_{2} \mathrm{O}(\mathrm{s}):-112.0(\mathrm{~N}), \mathrm{Cu}\left(\mathrm{IO}_{3}\right)_{2} \cdot 3 \mathrm{Cu}(\mathrm{OH})_{2}(\mathrm{~s}):-160.0(\mathrm{~N}), \mathrm{Cu}\left(\mathrm{HIO}_{3}\right)_{2}(\mathrm{~s}):-60.9(\mathrm{C})\end{array}$ \\
\hline $\mathrm{Fe}$ & $\begin{array}{l}\mathrm{Fe}(\mathrm{s}): 0.0, \mathrm{FeO}(\mathrm{s}):-60.1(\mathrm{~J}), \mathrm{Fe}(\mathrm{OH})_{2}(\mathrm{~s}):-116.3(\mathrm{~N}):-117.6(\mathrm{~J}) ; \mathrm{Fe}_{3} \mathrm{O}_{4}(\mathrm{~s}):-242.7(\mathrm{~N}) \\
\{-243.2(\mathrm{~J})\}, \mathrm{Fe}_{2} \mathrm{O}_{3}(\mathrm{~s}):-177.4(\mathrm{~N})\{-177.7(\mathrm{~J})\}, \mathrm{Fe}(\mathrm{OH})_{3}(\mathrm{~s}):-166.53(\mathrm{~N})\{-168.6(\mathrm{~J})\} \\
\mathrm{Fe}^{2+}(\mathrm{aq}):-18.9(\mathrm{~N}), \mathrm{Fe}^{3+}(\mathrm{aq}):-1.1(\mathrm{~N}), \mathrm{HFeO}_{2}{ }^{-}(\mathrm{aq}):-90.3(\mathrm{~N}), \mathrm{FeOH}^{2+}(\mathrm{aq}):-54.8(\mathrm{~N}), \\
\mathrm{Fe}(\mathrm{OH})_{2}{ }^{+}(\mathrm{aq}):-104.7(\mathrm{~N}), \mathrm{Fe}(\mathrm{OH})_{3}{ }^{-}(\mathrm{aq}):-147.0(\mathrm{~N}), \mathrm{Fe}(\mathrm{OH})_{4}{ }^{2-}(\mathrm{aq}):-184.0(\mathrm{~N}), \mathrm{FeI}^{2+} \\
(\mathrm{aq}):-16.0(\mathrm{~N}), \mathrm{FeI}_{2}(\mathrm{aq}):-43.5(\mathrm{~N}), \mathrm{FeI}_{2}(\mathrm{~s}):-26.7(\mathrm{~J}), \mathrm{FeI}_{3}(\mathrm{aq}):-38.1(\mathrm{~N})\end{array}$ \\
\hline $\mathrm{Ni}$ & $\begin{array}{l}\mathrm{Ni}(\mathrm{s}): 0.0, \mathrm{Ni}_{2} \mathrm{O}_{3}(\mathrm{~s}):-112.27(\mathrm{P}), \mathrm{Ni}_{3} \mathrm{O}_{4}(\mathrm{~s}):-170.15(\mathrm{P}), \mathrm{NiO}(\mathrm{s}):-51.3(\mathrm{P})\{-50.6(\mathrm{~N}) \\
-50.8(\mathrm{~B})\}, \mathrm{NiO}_{2}(\mathrm{~s}):-51.42(\mathrm{P}), \mathrm{Ni}(\mathrm{OH})_{2}(\mathrm{~s}):-108.3\left(\mathrm{P}^{\prime}\right)\{-106.9(\mathrm{~N})\}, \mathrm{Ni}^{2+}(\mathrm{aq}):-11.53(\mathrm{P}) \\
\{-10.9(\mathrm{~N})\}, \mathrm{HNiO}_{2}-(\mathrm{aq}):-83.5(\mathrm{P}, \mathrm{N}), \mathrm{NiI}_{2}(\mathrm{~s}):-19.3(\mathrm{~B}), \mathrm{NiI}_{2}(\mathrm{aq}):-35.6(\mathrm{~N}), \mathrm{Ni}^{\left(\mathrm{IO}_{3}\right)_{2}(\mathrm{~s}):} \\
-78.0(\mathrm{~N})\end{array}$ \\
\hline $\mathrm{Pt}$ & $\begin{array}{l}\mathrm{Pt}(\mathrm{s}): 0.0, \mathrm{PtO}(\mathrm{s}):-11.5(\mathrm{P}), \mathrm{PtO}_{2}(\mathrm{~s}):-20.0(\mathrm{P}), \mathrm{PtO}_{3}(\mathrm{~s}):-16.0(\mathrm{P}), \mathrm{Pt}^{2+}(\mathrm{aq}): 54.8(\mathrm{P}) \\
\{60.9(\mathrm{I})\}, \mathrm{PtI}_{4}(\mathrm{~s}):-17.9(\mathrm{~B}), \mathrm{PtI}_{6}{ }^{2-}(\mathrm{aq}):-26.0(\mathrm{I})\end{array}$ \\
\hline $\mathrm{Ta}$ & $\mathrm{Ta}(\mathrm{s}): 0.0, \mathrm{Ta}_{2} \mathrm{O}_{5}(\mathrm{~s}):-456.8(\mathrm{~B}), \mathrm{TaI}_{5}(\mathrm{~s}):-80.5(\mathrm{~B})$ \\
\hline $\mathrm{Ti}$ & $\begin{array}{l}\mathrm{Ti}(\mathrm{s}): 0.0, \mathrm{TiO}(\mathrm{s}):-116.9(\mathrm{P})\{-122.7(\mathrm{~J})\}, \mathrm{TiO}_{2}(\mathrm{Rutile})(\mathrm{s}):-212.3(\mathrm{P})\{-212.6(\mathrm{~J})\}, \mathrm{Ti}_{2} \mathrm{O}_{3}(\mathrm{~s}): \\
-342.3(\mathrm{P})\{-342.7(\mathrm{~J})\}, \mathrm{Ti}_{3} \mathrm{O}_{5}(\mathrm{~s}):-553.1(\mathrm{P})\{-553.9(\mathrm{~J})\}, \mathrm{TiO}^{2+}(\mathrm{aq}):-138.0(\mathrm{P}), \mathrm{Ti}^{2+}(\mathrm{aq}): \\
-75.1(\mathrm{P}), \mathrm{Ti}^{3+}(\mathrm{aq}):-83.6(\mathrm{P}), \mathrm{HTiO}_{3}{ }^{-}(\mathrm{aq}):-228.5(\mathrm{P}), \mathrm{TiO}_{2}{ }^{2+}(\mathrm{aq}):-111.7(\mathrm{P}), \mathrm{TiI}_{2}(\mathrm{~s}): \\
-61.9(\mathrm{~J}), \mathrm{TiI}_{3}(\mathrm{~s}):-76.1(\mathrm{~J}), \mathrm{TiI}_{4}(\mathrm{~s}):-88.6(\mathrm{~J})\end{array}$ \\
\hline $\mathrm{Zr}$ & $\begin{array}{l}\mathrm{Zr}(\mathrm{s}): 0.0, \mathrm{Zr}^{4+}(\mathrm{aq}):-142.0(\mathrm{P}), \mathrm{ZrO}^{2+}(\mathrm{aq}):-201.5(\mathrm{P}), \mathrm{HZrO}_{3}^{-}(\mathrm{aq}):-287.7(\mathrm{P}) \\
\mathrm{ZrO}_{2}(\mathrm{~s}):-248.5(\mathrm{P}, \mathrm{J}), \mathrm{ZrO}_{2} \cdot 2 \mathrm{H}_{2} \mathrm{O}(\mathrm{s}):-370.0\left(\mathrm{P}^{\prime}\right), \mathrm{ZrI}_{2}(\mathrm{~s}):-61.7(\mathrm{~J}), \mathrm{ZrI}_{3}(\mathrm{~s}):-94.4(\mathrm{~J}), \\
\mathrm{ZrI}_{4}(\mathrm{~s}):-116.0(\mathrm{~J})\end{array}$ \\
\hline
\end{tabular}

*a) g: gaseous, 1: liquid, s: solid, aq: aqueous

*b) units: $\mathrm{kcal} / \mathrm{mol}$

*c) References cited are as follows: 
(Table 1. continued)

P: Referred from Pourbaix's Atlas ${ }^{10)}$

$\mathrm{P}^{\prime}$ : Calculated from Gibbs energy of hydrated oxides of Pourbaix's Atlas ${ }^{10)}$, using the value of Gibbs energy of $\mathrm{H}_{2} \mathrm{O}$ equal to $-56.7 \mathrm{kcal} / \mathrm{mole}$

B: Calculated from Barin et al.'s Data ${ }^{11)}$

$\mathrm{J}$ : Referred from JANAF Thermochemical Tables ${ }^{12}$ )

C: Calculated from the stability constants of complexes from the data of "Critical Stability Constants" using the values of Gibbs energy of $\mathrm{I}^{-}, \mathrm{IO}_{3}^{-}$, etc. of Pourbaix's Atlas ${ }^{10)}$

$\mathrm{N}$ : Referred from the NBS "Selected Value of Chemical Thermodynamic Properties"14)

S: Calculated from the stability constants of complexes from the data of "Stability Constants of MetalIon Complexes"15)

I: Referred from the data of IUPAC's "Standard Potentials in Aqueous Solution"

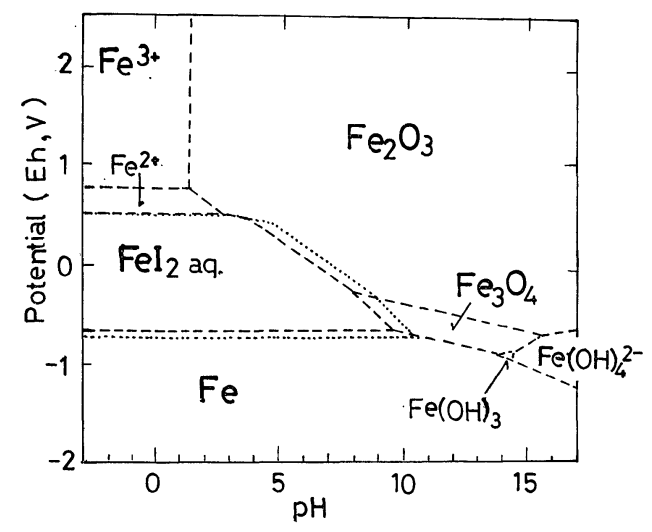

Fig. 4 Potential-pH diagram of $\mathrm{Fe}-\mathrm{I}-\mathrm{H}_{2} \mathrm{O}$.

Activities of dissolved iodine compounds are as follows:

......... : 100, ---: 10.

(Note: Stable area of $\mathrm{FeI}_{2}(\mathrm{aq})$ is present when above activities are 10 or 100 .)

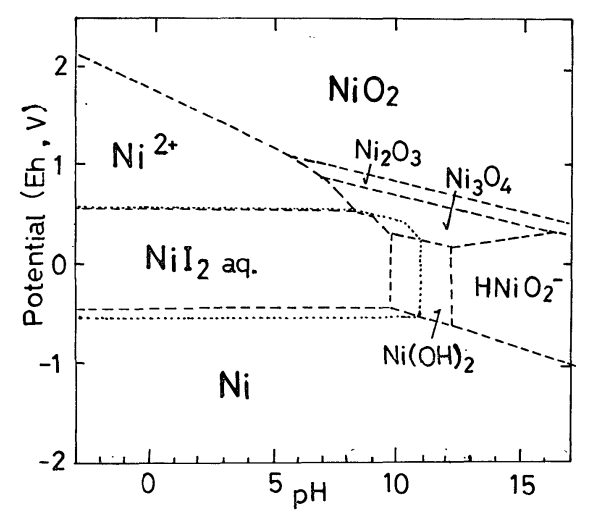

Fig. 5 Potentical-pH diagram of $\mathrm{Ni}-\mathrm{I}-\mathrm{H}_{2} \mathrm{O}$.

Activities of dissolved iodine compounds are as follows:

-........ : 100, ---: 10.

(Note: Stable area of $\mathrm{NiI}_{2}(\mathrm{aq})$ is present when above activities are 10 or 100 .)

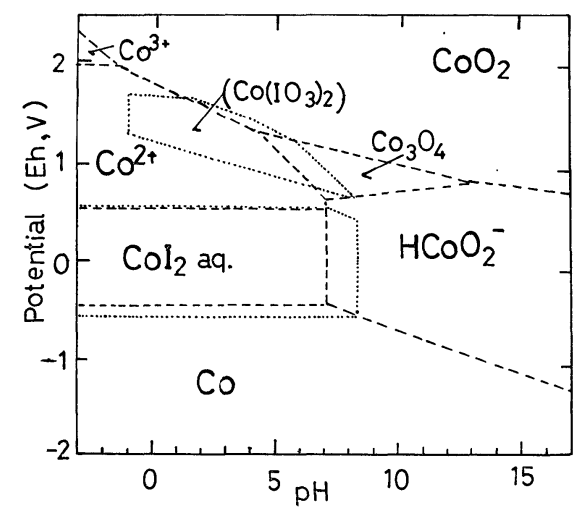

Fig. 6 Potential-pH diagram of $\mathrm{Co}-\mathrm{I}-\mathrm{H}_{2} \mathrm{O}$.

Activities of dissolved iodine compounds are as follows:

$$
\text { ….....: } 100,---: 1 \text {. }
$$

(Note: Stable area of $\mathrm{CoI}_{2}(\mathrm{aq})$ is present when above activities are 1,10 or 100 , and that of $\mathrm{Co}\left(\mathrm{IO}_{3}\right)_{2}(\mathrm{~s})$ is present when they are 10 or 100.)

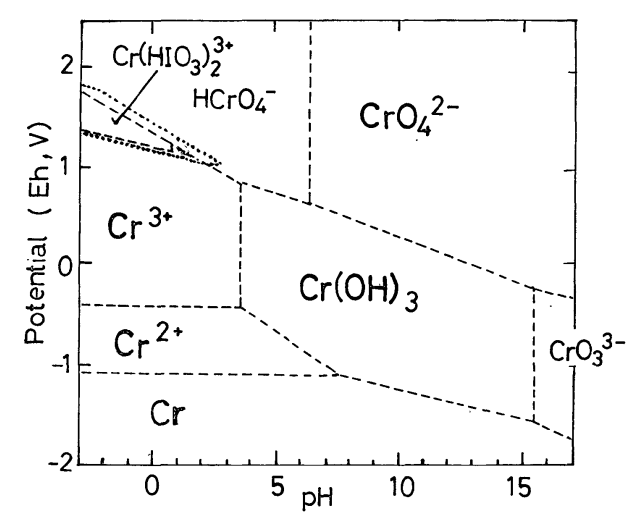

Fig. 7 Potential-pH diagram of $\mathrm{Cr}-\mathrm{I}-\mathrm{H}_{2} \mathrm{O}$.

Activities of dissolved iodine compounds are as follows:

$$
: 100,---: 0.1 \text {. }
$$

(Note: Stable area of $\mathrm{Cr}\left(\mathrm{HIO}_{3}\right)_{2}{ }^{3+}(\mathrm{aq})$ is present when above activities are $0.1,1,10$ or 100.) 
ly in various data compilations ${ }^{10) ~ 16)}$. Consistency anong the values is not necessarily guaranteed when the data from different sources are used. Therefore, we tried to select the data from a single source for each metal, if possible. If not possible, we are obliged to use the data from different sources. In this case, we tried to check if the data for the same compound from different sources have nearly equal values to each other. The adopted data are listed in Table 1 with their sources.

The calculations were done under the assumption that the activity of solid substance be 1.0 and that of dissolved corrosion product be $1.0 * 10^{-6}$, as is often assumed. The activities of the dissolved iodine compounds (i.e., $\mathrm{I}^{-}, \mathrm{I}_{3}^{-}, \mathrm{I}^{+}$, HIO, $\mathrm{IO}^{-}, \mathrm{HIO}_{3}, \mathrm{IO}_{3}{ }^{-}, \mathrm{HIO}_{4}, \mathrm{IO}_{4}{ }^{-}, \mathrm{HIO}_{5}{ }^{2-}$, and $\mathrm{IO}_{5}{ }^{3-}$ ), are assumed as $0.01,0.1,1,10$, or $100 *^{*}$ )

\section{Results and discussion}

Potential-pH diagrams of iron-group metals (i.e., iron, nickel, and cobalt) are presented in Figs. 4, 5, and 6, respectively. In dilute solution of iodine, where the activities of dissolved iodine compounds are less than 0.1 , no areas of predominance of iodides exist on the E-pH diagrams and we can consider the system as if there were no iodine from thermodynamic point of view. In the concentrated iodine solution, where the activities of dissolved iodine compounds are higher than $10^{* 77}$, the metal iodides in aqueous state is stable in low $\mathrm{pH}$ and rather less-noble region. The redox potential of $\mathrm{MgI}_{2}-\mathrm{I}_{2}-\mathrm{H}_{2} \mathrm{O}$ solution (molar ratio is 1: 1: 10) measured on tantalum electrode was about 0.42 volts ( $v s$. NHE) at room temperature ${ }^{1)}$ and the $\mathrm{pH}$ value is about 7 . Therefore, there is possibility that nickel and cobalt corrode in the form of iodides.

*6) It is difficult to estimate the activity of corrosive species in concentrated solution at high temperature and high pressure such as environments used in the experiments already reported ${ }^{1)}$. The experiments were done under several conditions but typical test solution contains 1 mole of $\mathrm{MgI}_{2}$, 0.2 moles of $\mathrm{Mg}\left(\mathrm{IO}_{3}\right)_{2}, 4.8$ moles of $\mathrm{I}_{2}$, and 9.6 moles of $\mathrm{H}_{2} \mathrm{O}$, which corresponds to the concentrationof about 70 grams-atom iodine in 1 liter $-\mathrm{H}_{2} \mathrm{O}$. We assumed the values as described, for it is considered that the absolute values of activity are not necessary for our purpose to do relative comparison among metals.

*7) As for $\mathrm{Co}, \mathrm{CoI}_{2}(\mathrm{aq})$, the activity of which is $1 \times$ $10^{-6}$, is just in equilibrium with $\mathrm{Co}^{2+}$ and $\mathrm{I}^{-}$when the activity of $\mathrm{I}^{-}$is 1.0 , which is presented in Fig. 6.

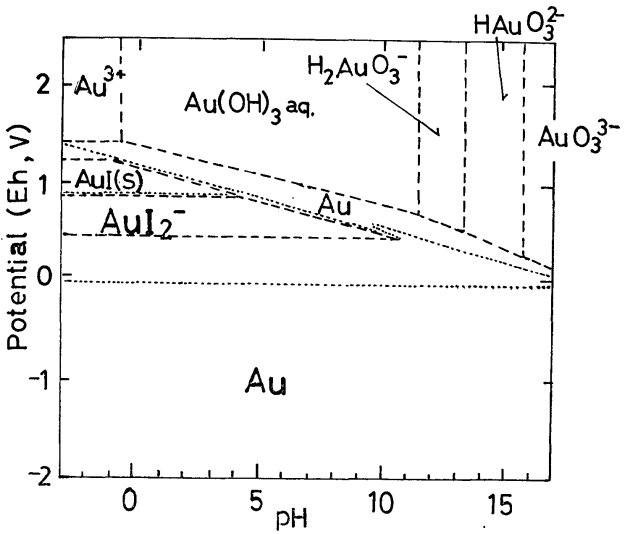

Fig. 8 Potential-pH diagram of $\mathrm{Au}-\mathrm{I}-\mathrm{H}_{2} \mathrm{O}$.

Activities of dissolved iodine compounds are as follows:

….....: $100,---: 0.01$.

(Note: Stable areas of $\mathrm{AuI}(\mathrm{s})$ and $\mathrm{AuI}_{2}{ }^{-}$are present when above activities are $0.01,0.1$, 1,10 or 100 .)

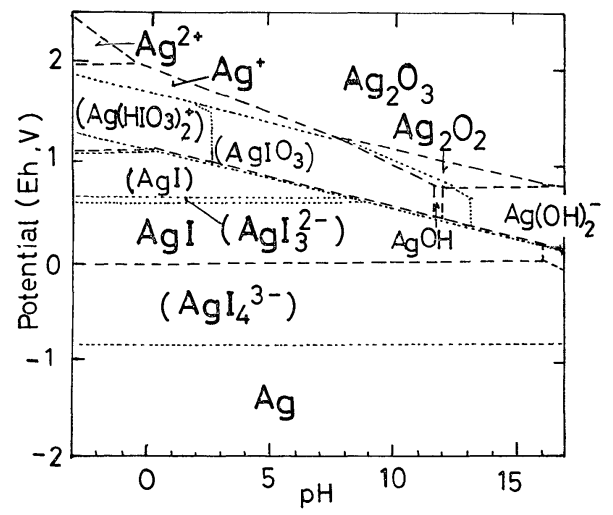

Fig. 9 Potential-pH diagram of $\mathrm{Ag}-\mathrm{I}-\mathrm{H}_{2} \mathrm{O}$.

Activities of dissolved iodine compounds are as follows:

$$
: 100,---: 0.01 \text {. }
$$

(Note: Stable area of $\mathrm{AgI}(\mathrm{s})$ is present when above activities are $0.01,0.1,1,10$ or 100 . That of $\mathrm{AgI}_{3}{ }^{2-}(\mathrm{aq})$ is present when they are $0.1,1,10$ or 100 . Those of $\mathrm{AgI}_{4}{ }^{3-}$ (aq), $\mathrm{AgIO}_{3}(\mathrm{~s})$, and $\mathrm{Ag}\left(\mathrm{HIO}_{3}\right)_{2}{ }^{+}(\mathrm{aq})$ are present when they are 1,10 or 100 .)

As for chromium, which is the most common alloying element for ferrous materials and nickel alloys, chromium idoides are less stable than $\mathrm{Cr}^{3+}, \mathrm{Cr}^{2+}$, or $\mathrm{Cr}(\mathrm{OH})_{3}$, etc. and only $\mathrm{Cr}\left(\mathrm{HIO}_{3}\right)_{2}{ }^{3+}$ shows stable region among iodine-containing species, as shown in Fig. 7. The redox potential and the $\mathrm{pH}$ value above mentioned lies in the 


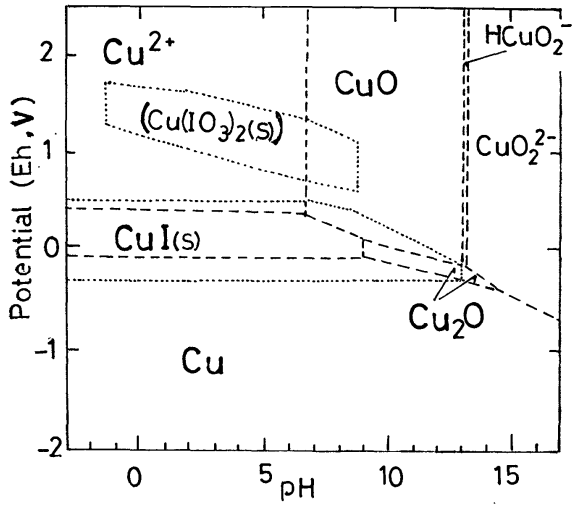

Fig. 10 Potential-pH diagram of $\mathrm{Cu}-\mathrm{I}-\mathrm{H}_{2} \mathrm{O}$.

Activities of dissolved iodine compounds are as follows:

$$
: 100 \text {, - - : } 0.01 \text {. }
$$

(Note: Stable area of CuI(s) is present when above activities are $0.01,0.1,1,10$ or 100 . That of $\mathrm{Cu}\left(\mathrm{IO}_{3}\right)_{2}(\mathrm{~s})$ is present when they are 1, 10 or 100 .)

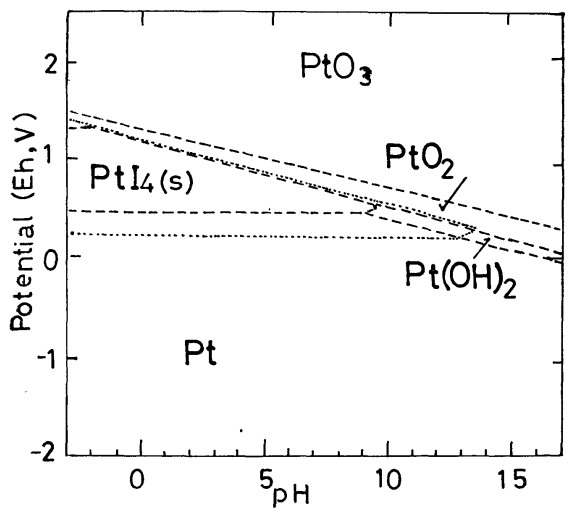

Fig. 11 Potential-pH diagram of Pt-I- $\mathrm{H}_{2} \mathrm{O}$.

Activities of dissolved iodine compounds are as follows:

$$
\text { …....: } 100 \text {, ---: } 0.01 \text {. }
$$

(Note: Stable area of $\mathrm{PtI}_{4}(\mathrm{~s})$ is present when above activities are $0.01,0.1,1,10$ or 100 .)

stable area of $\mathrm{Cr}(\mathrm{OH})_{3}$ (or hydrated $\mathrm{Cr}_{2} \mathrm{O}_{3}$ ). Therfore, it is expected that $\mathrm{Cr}$ may be protective in the concentrated iodine solution, such as in the environments used in our experiments. However, the experiments ${ }^{1)}$ of $\mathrm{Cr}, \mathrm{Ni}-\mathrm{Cr}$ alloys and Incoloy

*8) The protectiveness of $\mathrm{Cr}$ metal in that solution could not be determined definitely in the experiment, for the $\mathrm{Cr}$ plate tested broke down perhaps because of embrittlement of grain boundary.
600 gave negative results*8) in solutions with slightly different composition (including more iodine and $\mathrm{Mg}\left(\mathrm{IO}_{3}\right)_{2}$ than the solution where the redox potential and $\mathrm{pH}$ was measured) at high temperature. Rather good (but unstable) protectiveness was observed for Hastelloy-C, which may be attributed to the co-existence of Mo and $\mathrm{Cr}$ in that alloy, but the reason is not clear up to now.

Noble metals such as gold, silver, copper and platinum are the typical examples where there is great difference between the systems with and without iodine, as shown in Figs. 8, 9, 10, and 11, respectively. For instance, although $\mathrm{Au}$ is stable in the whole region of stability of water in metalwater system ${ }^{10)}$, the presence of small amount of iodine (activity is 0.01 ) dissolves $\mathrm{Au}$ in the form of $\mathrm{AuI}_{2}{ }^{-}(\mathrm{aq})$. Pt corrodes also by forming of $\mathrm{PtI}_{4}(\mathrm{~s})$, but not of $\mathrm{PtI}_{6}{ }^{2-}(\mathrm{aq})$. The corrosion rate of $\mathrm{Pt}$ will be smaller than $\mathrm{Au}$, since the solid iodide film shows protective nature, to some extent, on the surface of Pt. These predictions agree to the experimental data of corrosion rates ${ }^{1)}$.

As for titanium, zirconium, and tantalum, no stable area of iodides are present on the E-pH diagram and the E-pH diagrams of metal-iodinewater system are the same as those of metal-water system, even when the activity of dissolved iodine compounds is 100 , thus the results are omitted in this paper. This suggests that these metals are expected to be protective in concentrated iodine solution because tight oxide films (e.g., $\mathrm{TiO}_{2}$, $\mathrm{ZrO}_{2} \cdot 2 \mathrm{H}_{2} \mathrm{O}$, and $\mathrm{Ta}_{2} \mathrm{O}_{5}$ ) are thermodynamically more stable than iodides considered.

In summary, thermodynamical prediction at $25^{\circ} \mathrm{C}$ as described above is fairly in good agreement with the experimental results at high temperature reported before ${ }^{1)}$, when substances listed in table 1 are taken into consideration, though credible thermodynamical data of iodides and iodine complexes are not necessarily available for all the elements considered. From the experimental data, $\mathrm{Fe}-, \mathrm{Ni}-$, and Co- alloys and metals as well as $\mathrm{Au}$, $\mathrm{Ag}$, and $\mathrm{Pt}$ corrode in the concentrated iodine solutions, but $\mathrm{Ti}, \mathrm{Zr}$, and $\mathrm{Ta}$ are rather protective. The insufficient stability of passive film of Ti and $\mathrm{Zr}$, compared to $\mathrm{Ta}$, observed in the experiments may be interpreted by further consideration of the temperature dependence of thermodynamic functions and/or unknown complexes of these metals.

\section{Conclusion}

An improved algorithm for computer-aided 
construction of the potential-pH diagrams of metalion-water system was demonstrated and applied to the metal-iodine-water systems. Thermodynamic data are not always available for each compound to be considered, but the following predications were derived in the present case: (1) $\mathrm{Ta}, \mathrm{Ti}$, and $\mathrm{Zr}$ are protective in concentrated iodine solution because of oxide film formation; (2) $\mathrm{Au}, \mathrm{Ag}$ and Pt will corrode because of the formation of iodine complexes or less protective solid iodides. (3) Fe, $\mathrm{Ni}$, and Co will corrode rapidly. There is a possibility of iodide formation in case of $\mathrm{Ni}$ and $\mathrm{Co}$ in concentrated iodine solutions. These thermodynamic predictions are fairly in good agreement with the experimental results, in spite of the lack of the estimation of the values of thermodynamic functions at high temperature.

\section{Acknowledgement}

The authors wish to express their sincere gratitude to Dr. Toshiaki Kodama, National Research Institute of Metals, and Dr. Hideo Hirano, Central Research Institute of Electric Power Industry, for their helpful discussions and informations.

(Received October 29, 1986)

\section{References}

1) H. Sasaki, Y. Kanda, Y. Imai, \& H. Togano: Boshoku Gijutsu, 31, 691 (1982).

2) P. A. Brook: Corros. Sci., 11, 389 (1971).

3) M. H. Froning, M. E. Shanley, \& E. D. Verink, Jr.: Corros. Sci., 16, 371 (1976).

4) B. H. Rosof: in "Applications of Phase Di- agrams in Metallurgy and Ceramics" (NBS Special Publication 496), p, 1090 (1977).

5) B. G. Williams \& W. H. Patrick, Jr.: J. Chem. Educ., 54, 107 (1977).

6) P. B. Linkson, B. D. Phillips, \& C. D. Powles: Corros. Sci., 19, 613 (1979).

7) J. C. Angus \& C. T. Angus: J. Electrochem. Soc., 132, 1014 (1985).

8) C. M. Chen \& K. Aral: Corrosion, 38, 183 (1982).

9) A. A. Mufti: "Elementary Computer Graphics", Chap. 7, Reston Pub. (1982).

10) M. Pourbaix: "Atlas of Electrochemical Equilibria in Aqueous Solutions", Pergamon Press, Oxford (1966).

11) I. Barin \& O. Knacke: "Thermochemical Properties of Inorganic Substances", Springer Verlag, Berlin (1973; supplement 1977).

12) M. W. Chase et al. ed. "JANAF Thermochemical Tables" 2nd ed. (1971); D. R. Stull et al. ed.: J. Phys. Chem. Ref. Data, 3, 311 (1974); 4, 1 (1975); 7, 793 (1978); 11, 695 (1982).

13) R. M. Smith \& A. E. Martell: "Critical Stability Constants" vol. 4, Plenum Press, New York (1976).

14) D. D. Wagman et al. ed.: "Selected Values of Chemical Thermodynamic Properties" (NBS Technical Note 270-3 270-8), (1968, 69, 71, $71,73,81)$.

15) E. Högfelds: "Stability Constants of MetalIon Complexes, Part-A Inorganic Ligands" (IUPAC Chemical Data Series No. 21), Pergamon Press, Oxford (1982).

16) A. J. Bard, R. Parson, \& J. Jordan: "Standard Potentials in Aqueous Solution", IUPAC, Marcel Dekker, Inc., New York (1985).

17) J. Bouet \& P. Brenet: Corros. Sci., 3, 51 (1963). 